\title{
Flavobacterium terrae sp. nov. and Flavobacterium cucumis sp. nov., isolated from greenhouse soil
}

Correspondence

Soon-Wo Kwon

swkwon@rda.go.kr

\author{
Hang-Yeon Weon, ${ }^{1}$ Myung-Hee Song, ${ }^{2}$ Jung-A Son, ${ }^{1}$ Byung-Yong Kim, ${ }^{2}$ \\ Soon-Wo Kwon, ${ }^{2}$ Seung-Joo Go ${ }^{2}$ and Erko Stackebrandt ${ }^{3}$
}

\begin{abstract}
${ }^{1}$ Applied Microbiology Division, National Institute of Agricultural Science and Technology, Rural Development Administration (RDA), Suwon 441-707, Republic of Korea

${ }^{2}$ Korean Agricultural Culture Collection (KACC), Microbial Genetics Division, National Institute of Agricultural Biotechnology, Rural Development Administration (RDA), Suwon 441-707, Republic of Korea

${ }^{3} \mathrm{DSMZ}$ - Deutsche Sammlung von Mikroorganismen und Zellkulturen GmbH, Inhoffenstrasse 7b, D-38124 Braunschweig, Germany
\end{abstract}

Two bacterial strains, R2A1-13 ${ }^{\top}$ and $R 2 A 45-3^{\top}$, were isolated from greenhouse soils in Korea. The cells of both strains were Gram-negative, aerobic and rod-shaped. 16S rRNA gene sequence analysis placed the isolates in the genus Flavobacterium within the family Flavobacteriaceae. Strain R2A $1-13^{\top}$ was found to be related to Flavobacterium columnare IAM $14301^{\top}$, Flavobacterium saliperosum CGMCC1.3801 ${ }^{\top}$ and Flavobacterium croceum EMB47 ${ }^{\top}$, with sequence similarities of $96.8,95.0$ and $94.6 \%$, respectively. Strain R2A45-3 ${ }^{\top}$ was found to be related to $F$. croceum EMB $47^{\top}$ and Flavobacterium aquatile ATCC $11947^{\top}$, with sequence similarities of 94.7 and $94.6 \%$, respectively. Both strains contained iso- $C_{15: 0}$ and iso- $C_{16: 0}$ as the main fatty acids and contained a menaquinone with six isoprene units (MK-6) as the major isoprenoid quinone. The $G+C$ contents of the DNA from strains $R 2 A 1-13^{T}$ and $R 2 A 45-3^{T}$ were 34 and 38 mol\%, respectively. A polyphasic taxonomic study revealed that these strains belong to two novel species within the genus Flavobacterium, for which the names Flavobacterium terrae sp. nov. and Flavobacterium cucumis sp. nov. are proposed. The type strains of $F$. terrae sp. nov. and $F$. cucumis sp. nov. are R2A1-13 ${ }^{\top}\left(=\right.$ KACC $\left.11731^{\top}=\mathrm{DSM} 18829^{\top}\right)$ and R2A45-3 ${ }^{\top}(=\mathrm{KACC}$ $11732^{\top}=$ DSM $\left.18830^{\top}\right)$, respectively.
Since the genus Flavobacterium was proposed by Bergey et al. (1923), the description of this genus has been revised several times (Bernardet et al., 1996). Since 2005, the following novel species of the genus Flavobacterium have been described: Flavobacterium antarcticum, F. croceum, $F$. daejeonense, F. denitrificans, F. frigidimaris, F. fryxellicola, F. granuli, F. indicum, F. psychrolimnae, F. saliperosum, $F$. segetis, $F$. soli, $F$. suncheonense and $F$. weaverense (Aslam et al., 2005; Horn et al., 2005; Nogi et al., 2005; Van Trappen et al., 2005; Yi et al., 2005; Kim et al., 2006; Park et al., 2006; Saha \& Chakrabarti, 2006; Wang et al., 2006; Yi \& Chun, 2006; Yoon et al., 2006). Flavobacterium ferrugineum has also been reclassified as Terrimonas ferruginea (Xie \& Yokota, 2006).

In the present study, soil samples were collected from greenhouses planted with lettuce (Lactuca sativa L.) and cucumber (Cucumis sativus L.) in the Daejeon and Sangju

The GenBank/EMBL/DDBJ accession numbers for the 16S rRNA gene sequences of strains R2A $1-13^{\top}$ and R2A45-3 $3^{\top}$ are EF117329 and EF126993, respectively. regions of Korea. Soil samples were suspended in sterilized water and then diluted solutions were spread on R2A agar (Difco) and incubated at $30^{\circ} \mathrm{C}$. Two bacterial isolates, $\mathrm{R} 2 \mathrm{~A} 1-13^{\mathrm{T}}$ and $\mathrm{R} 2 \mathrm{~A} 45-3^{\mathrm{T}}$, were obtained; they were grown routinely on $\mathrm{R} 2 \mathrm{~A}$ medium at $30^{\circ} \mathrm{C}$.

The $16 \mathrm{~S}$ rRNA gene was amplified by using a PCR with two universal primers as described previously (Kim et al., 2006). BLAST searches in GenBank were used to identify species that were related to the novel isolates and the sequences of the two isolates (about $1430 \mathrm{bp}$ ) were aligned by using CLUSTAL W software (Thompson et al., 1994). The phylogenetic tree was constructed using the neighbour-joining method (Saitou \& Nei, 1987) and maximum parsimony (Fitch, 1971) in the MEGA3 program (Kumar et al., 2004). The stability of the relationships was assessed by means of bootstrapping (based on 1000 replicates).

In the neighbour-joining phylogenetic tree (Fig. 1), the two isolates were clearly grouped within the genus Flavobacterium. Strain R2A1-13 ${ }^{\mathrm{T}}$ shared $96.8 \%$ 16S rRNA gene sequence similarity with Flavobacterium columnare IAM 


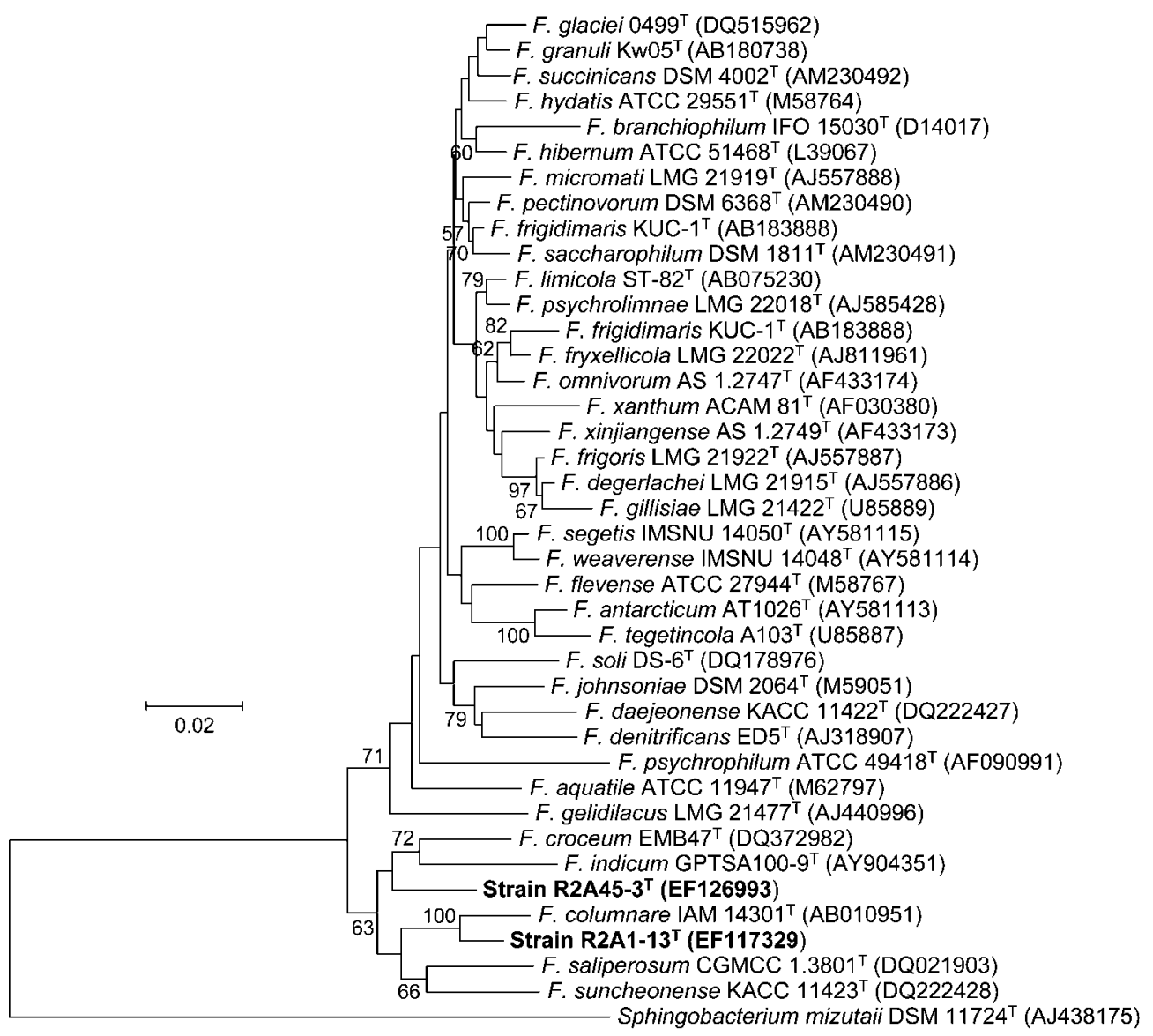

Fig. 1. Neighbour-joining phylogenetic tree, based on $16 S$ rRNA gene sequences, for $R 2 A 1-13^{\top}, R 2 A 45-3^{\top}$ and Flavobacterium species. Numbers at branch nodes are bootstrap percentages based on 1000 resamplings; only values greater than $50 \%$ are shown. Bar, 0.02 substitutions per nucleotide position. Sphingobacterium mizutaii DSM $11724^{\top}$ was used as an outgroup. The maximum-parsimony tree showed essentially the same topology (not shown).

$14301^{\mathrm{T}}$ (100\% bootstrap support). It also shared relatively high levels of sequence similarity with $F$. saliperosum CGMCC $1.3801^{\mathrm{T}}(95.0 \%)$ and $F$. croceum $\mathrm{EMB}^{\mathrm{T}} \mathrm{T}^{\mathrm{T}}$ $(94.6 \%)$. Strain R2A45-3 ${ }^{\mathrm{T}}$ was related to $F$. croceum EMB $47^{\mathrm{T}}$ and Flavobacterium aquatile ATCC $11947^{\mathrm{T}}$, with sequence similarities of 94.7 and $94.6 \%$, respectively. The maximum-parsimony tree showed essentially the same topology.

Biochemical and physiological tests were performed as described by Kim et al. (2006). The cells of both strains were Gram-negative, aerobic and rod-shaped, growing well on R2A and nutrient agar (Difco), weakly on tryptic soy agar (Difco) and not at all on MacConkey agar (Difco). Strain R2A $1-13^{\mathrm{T}}$ could be differentiated from its closest relative, F. columnare, by the absence of gliding motility, by the ability to grow on nutrient agar and tryptic soy agar and by the ability to hydrolyse starch. Strain R2A45-3 $3^{\mathrm{T}}$ could be distinguished from F. croceum by the ability of the former to grow on nutrient agar and to hydrolyse starch. Additional phenotypic characteristics that served to differentiate the two strains and other related Flavobacterium species are shown in Table 1.

Chemotaxonomic characteristics were determined from cells grown at $30^{\circ} \mathrm{C}$ for 1 day on R2A medium. Analysis of the fatty acid methyl esters was performed by using GLC according to the instructions of the Microbial Identification System (MIDI). Isoprenoid quinones were analysed by using HPLC as described previously (Groth et al., 1996). The DNA $\mathrm{G}+\mathrm{C}$ contents of the isolates were determined by using the HPLC method described by Mesbah et al. (1989), with a reversed-phase column (Supelcosil LC-18 S; Supelco).

The major fatty acids in both strains were iso- $\mathrm{C}_{15: 0}$ and iso$\mathrm{C}_{16: 0}$. The detailed fatty acid compositions are shown in Table 2. Both strains contained a menaquinone with six isoprene units (MK-6) as the major isoprenoid quinone. The $\mathrm{G}+\mathrm{C}$ contents of the DNA of strains R2A1-13 ${ }^{\mathrm{T}}$ and $\mathrm{R} 2 \mathrm{~A} 45-3^{\mathrm{T}}$ were 34 and $38 \mathrm{~mol} \%$, respectively.

On the basis of the data obtained in this polyphasic taxonomic study, strains $\mathrm{R} 2 \mathrm{~A} 1-13^{\mathrm{T}}$ and $\mathrm{R} 2 \mathrm{~A} 45-3^{\mathrm{T}}$ represent 
Table 1. Physiological and biochemical characteristics of strains $R 2 A 1-13^{\top}$ and $R 2 A 45-3^{\top}$ and related Flavobacterium species

Strains: 1, R2A1-13 ${ }^{\mathrm{T}}$; 2, R2A45-3 ${ }^{\mathrm{T}}$; 3, F. aquatile (data from Bernardet et al., 1996); 4, F. columnare

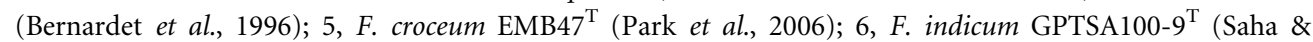
Chakrabarti, 2006); 7, F. saliperosum JCM $13331^{\mathrm{T}}$ (Wang et al., 2006); 8, F. suncheonense KACC $11423^{\mathrm{T}}$ (Kim et al., 2006). +, Positive; -, negative; (+), weakly positive; V, variable among references according to Bernardet et al. (1996).

\begin{tabular}{|lcccccccc|}
\hline Characteristic & $\mathbf{1}$ & $\mathbf{2}$ & $\mathbf{3}$ & $\mathbf{4}$ & $\mathbf{5}$ & $\mathbf{6}$ & $\mathbf{7}$ & $\mathbf{8}$ \\
\hline Colony pigmentation* & YO & $\mathrm{Y}$ & $\mathrm{CY}$ & $\mathrm{GY}$ & $\mathrm{Y}$ & $\mathrm{YO}$ & $\mathrm{Y}$ & $\mathrm{Y}$ \\
Growth on: & & & & & & & & \\
$\quad$ Nutrient agar & + & + & - & - & - & $(+)$ & + & + \\
$\quad$ Tryptic soy agar & $(+)$ & $(+)$ & + & - & $(+)$ & - & + & $(+)$ \\
Oxidase/catalase & $+/-$ & $+/+$ & $+/+$ & $+/+$ & $+/-$ & $+/(+)$ & $-/+$ & $+/+$ \\
Gliding motility & - & + & + & + & - & - & - & - \\
Flexirubin-type pigments & + & - & - & + & - & - & + & - \\
Nitrate reduction & - & - & $\mathrm{V}$ & $\mathrm{V}$ & - & - & - & - \\
Hydrolysis of: & & & & & & & & \\
$\quad$ Aesculin & - & + & $\mathrm{V}$ & - & - & - & - & - \\
$\quad$ Gelatin & + & + & $\mathrm{V}$ & + & + & + & + & + \\
$\quad$ Starch & + & + & $\mathrm{V}$ & - & - & + & - & - \\
$\quad$ Tyrosine & - & + & $\mathrm{V}$ & - & - & - & + & + \\
DNA G+C content (mol\%) & 34 & 38 & 33 & 32 & 41 & 31 & 41 & 39 \\
\hline
\end{tabular}

${ }^{\star} \mathrm{CY}$, Cream-yellow; GY, greenish yellow; Y, yellow; YO, yellowish orange.

two novel Flavobacterium species, for which the names Flavobacterium terrae sp. nov. and Flavobacterium cucumis sp. nov. are proposed.

\section{Description of Flavobacterium terrae sp. nov.}

Flavobacterium terrae (ter' rae. L. gen. n. terrae of the soil).

Cells are Gram-negative, non-spore-forming rods, $0.5 \times$ 2.5-4.5 $\mu \mathrm{m}$. Colonies on R2A medium are yellowish-orange with irregular edges. Growth occurs at $5-37{ }^{\circ} \mathrm{C}$ (optimum, $30{ }^{\circ} \mathrm{C}$ ), at $\mathrm{pH} 6-8$ (optimum, $\mathrm{pH} 7$ ) and with $0-2 \% \mathrm{NaCl}$ (optimum, 0-2\%). Oxidase-positive. Catalase-negative. Gliding motility is not observed. Flexirubin-type pigments are present. Negative for nitrate reduction, indole and arginine dihydrolase production, glucose fermentation and urease and aesculin hydrolysis (API 20NE test strip). Casein, gelatin and starch are hydrolysed, but alginic acid, chitin, CM-cellulose, DNA, pectin, tyrosine and urea are not. D-Glucose, L-arabinose, D-mannose, D-mannitol, $N$-acetylglucosamine, D-maltose, potassium gluconate, capric acid, adipic acid, malic acid, trisodium citrate and phenylacetic acid are not assimilated (API 20NE test strip). Alkaline phosphatase, esterase (C4), esterase lipase (C8), leucine arylamidase, valine arylamidase, cystine arylamidase, acid phosphatase, naphthol-AS-BI-phosphohydrolase and $\alpha$ glucosidase activities are present; lipase (C14), trypsin, $\alpha$ chymotrypsin, $\alpha$-galactosidase, $\beta$-galactosidase, $\beta$-glucuronidase, $\beta$-glucosidase, $N$-acetyl- $\beta$-glucosaminidase, $\alpha$-mannosidase and $\alpha$-fucosidase activities are absent (API ZYM test strip). MK-6 is the major respiratory lipoquinone. The major fatty acids are iso- $\mathrm{C}_{15: 0}$ and iso- $\mathrm{C}_{16: 0}$. The $\mathrm{G}+\mathrm{C}$ content of the genomic DNA is $34 \mathrm{~mol} \%$.

The type strain, R2A1-13 ${ }^{\mathrm{T}}$ (= KACC $11731^{\mathrm{T}}=\mathrm{DSM}$ $18829^{\mathrm{T}}$ ), was isolated from greenhouse soil cultivated with lettuce in the Daejeon region of Korea.

\section{Description of Flavobacterium cucumis sp. nov.}

Flavobacterium cucumis (cu' cu.mis. L. gen. n. cucumis of the cucumber, referring to the isolation source of the type strain, a soil cultivated with cucumber plants).

Cells are Gram-negative, non-spore-forming rods, $0.5 \times$ 2.0-3.0 $\mu \mathrm{m}$. Colonies on R2A medium are yellow with irregular edges. Growth occurs at $5-37^{\circ} \mathrm{C}$ (optimum, $30{ }^{\circ} \mathrm{C}$ ), at $\mathrm{pH}$ 6-8 (optimum, $\mathrm{pH} 7$ ) and with $0-2 \% \mathrm{NaCl}$ (optimum, 0-2\%). Catalase- and oxidase-positive. Gliding motility is observed. Flexirubin-type pigments are not present. Negative for nitrate reduction, indole and arginine dihydrolase production and glucose fermentation (API 20NE test strip). Aesculin, casein, gelatin, starch and tyrosine are hydrolysed, but alginic acid, chitin, CM-cellulose, DNA, pectin and urea are not. D-Glucose, L-arabinose, D-mannose, D-mannitol, $\mathrm{N}$-acetylglucosamine, D-maltose, potassium gluconate, capric acid, adipic acid, malic acid, trisodium citrate and phenylacetic acid are not assimilated (API 20NE test strip). Alkaline phosphatase, esterase (C4), esterase lipase (C8), leucine arylamidase, valine arylamidase, 
Table 2. Cellular fatty acid compositions of strains $R 2 A 1-13^{T}$ and $R 2 A 45-3^{T}$ and related Flavobacterium type strains

Strains: 1, R2A1-13 ${ }^{\mathrm{T}} ; 2$, R2A45-3 ${ }^{\mathrm{T}} ; 3$, F. aquatile DSM $1132^{\mathrm{T}} ; 4$, F. columnare LMG $13035^{\mathrm{T}} ; 5$, F. croceum EMB47 ${ }^{\mathrm{T}}$ (data from Park et al., 2006); 6, F. indicum GPTSA100-9 ${ }^{\mathrm{T}}$ (Saha \& Chakrabarti, 2006); 7, F. saliperosum JCM $13331^{\mathrm{T}}$ (data in columns $1-4$ and 7 are from this study); 8 , F. suncheonense KACC $11423^{\mathrm{T}}$ (Kim et al., 2006). -, <1\% or not detected; NR, not reported.

\begin{tabular}{|c|c|c|c|c|c|c|c|c|}
\hline Fatty acid & 1 & 2 & 3 & 4 & 5 & 6 & 7 & 8 \\
\hline iso- $\mathrm{C}_{13: 0}$ & - & - & - & 1.3 & 1.0 & NR & - & 1.9 \\
\hline iso- $\mathrm{C}_{14: 0}$ & 4.7 & 5.3 & 3.1 & 3.8 & 8.7 & NR & - & - \\
\hline iso- $\mathrm{C}_{14: 0} 3-\mathrm{OH}$ & 1.1 & 1.8 & - & 1.5 & 2.6 & $\mathrm{NR}$ & - & - \\
\hline $\mathrm{C}_{15: 0}$ & - & - & - & - & 10.8 & NR & - & - \\
\hline $\mathrm{C}_{15: 0} 2-\mathrm{OH}$ & - & - & - & - & 2.0 & NR & - & - \\
\hline $\mathrm{C}_{15: 0} 3-\mathrm{OH}$ & 2.2 & 1.5 & 2.1 & 1.9 & 1.3 & NR & - & - \\
\hline anteiso- $\mathrm{C}_{15: 0}$ & 2.8 & 4.4 & 3.5 & 2.2 & 5.1 & NR & 4.4 & 2.1 \\
\hline anteiso- $\mathrm{C}_{15: 1} \mathrm{~A}$ & - & - & - & - & 1.6 & NR & - & - \\
\hline iso- $\mathrm{C}_{15: 0}$ & 18.4 & 17.5 & 17.0 & 30.1 & 9.3 & 18.5 & 25.6 & 29.9 \\
\hline iso- $\mathrm{C}_{15: 0} 3-\mathrm{OH}$ & 6.7 & 5.1 & 6.4 & 5.2 & 5.9 & 5.0 & 4.8 & 11.1 \\
\hline iso- $\mathrm{C}_{15: 1} \mathrm{G}$ & 10.7 & 9.9 & 7.4 & 14.6 & 11.5 & 18.0 & 6.6 & 12.0 \\
\hline $\mathrm{C}_{15: 1} \omega 6 c$ & 1.1 & 2.0 & 10.8 & - & - & NR & 1.3 & - \\
\hline $\mathrm{C}_{16: 0}$ & - & 1.2 & 2.6 & 1.1 & 1.0 & NR & 1.1 & 1.0 \\
\hline $\mathrm{C}_{16: 0} 3-\mathrm{OH}$ & 1.3 & 1.7 & 2.3 & - & - & $\mathrm{NR}$ & - & - \\
\hline iso- $\mathrm{C}_{16: 0}$ & 16.6 & 18.8 & 7.2 & 8.7 & 8.5 & 5.1 & 11.5 & 1.0 \\
\hline iso- $\mathrm{C}_{16: 0} 3-\mathrm{OH}$ & 5.0 & 12.6 & 10.4 & 7.4 & 16.5 & 4.5 & 2.4 & - \\
\hline iso- $\mathrm{C}_{16: 1} \mathrm{G}$ & 3.0 & - & - & - & 2.9 & $\mathrm{NR}$ & - & - \\
\hline iso- $\mathrm{C}_{16: 1} \mathrm{H}$ & - & 4.0 & 2.9 & 4.1 & - & NR & 2.1 & - \\
\hline $\mathrm{C}_{17: 0} 2-\mathrm{OH}$ & - & - & - & - & - & $\mathrm{NR}$ & 1.8 & - \\
\hline $\mathrm{C}_{17: 0} 3-\mathrm{OH}$ & 1.5 & - & 1.1 & - & - & NR & - & - \\
\hline iso- $\mathrm{C}_{17: 0} 3-\mathrm{OH}$ & 10.3 & 5.3 & 6.5 & 6.6 & 2.7 & 9.0 & 10.3 & 17.7 \\
\hline $\mathrm{C}_{17: 1} \omega 6 c$ & - & - & 2.5 & - & - & NR & - & - \\
\hline $\mathrm{C}_{17: 1} \omega 8 c$ & - & - & 1.3 & - & - & NR & - & - \\
\hline iso- $\mathrm{C}_{17: 1} \omega 9 c$ & 6.2 & 1.5 & 1.5 & 3.7 & - & NR & 17.9 & 7.5 \\
\hline Summed feature $3^{*}$ & 1.3 & 2.0 & 7.0 & - & 3.6 & 16.6 & 2.3 & 9.8 \\
\hline
\end{tabular}

${ }^{*}$ Summed feature 3 comprises iso- $\mathrm{C}_{15: 0} 2-\mathrm{OH}$ and/or $\mathrm{C}_{16: 1} \omega 7 c$.

cystine arylamidase, trypsin, $\alpha$-chymotrypsin, acid phosphatase, naphthol-AS-BI-phosphohydrolase and $\alpha$-glucosidase activities are present; lipase (C14), $\alpha$-galactosidase, $\beta$ galactosidase, $\beta$-glucuronidase, $\beta$-glucosidase, $N$-acetyl- $\beta$ glucosaminidase, $\alpha$-mannosidase and $\alpha$-fucosidase activities are absent (API ZYM test strip). MK-6 is the major respiratory lipoquinone. The major fatty acids are iso- $\mathrm{C}_{15: 0}$ and iso- $\mathrm{C}_{16: 0}$. The $\mathrm{G}+\mathrm{C}$ content of the genomic DNA is $38 \mathrm{~mol} \%$.

The type strain, R2A45-3 $3^{\mathrm{T}} \quad$ (= KACC $11732^{\mathrm{T}}=\mathrm{DSM}$ $18830^{\mathrm{T}}$ ), was isolated from greenhouse soil cultivated with cucumber in the Sangju region of Korea.

\section{Acknowledgements}

This work was supported by a grant (no. 06-4-11-19-3) of the National Institute of Agricultural Biotechnology, Rural Development Administration, Republic of Korea.

\section{References}

Aslam, Z., Im, W. T., Kim, M. K. \& Lee, S. T. (2005). Flavobacterium granuli sp. nov., isolated from granules used in a wastewater treatment plant. Int J Syst Evol Microbiol 55, 747-751.

Bergey, D. H., Harrison, F. C., Breed, R. S., Hammer, B. W. \& Huntoon, F. M. (editors) (1923). Bergey's Manual of Determinative Bacteriology. Baltimore: Williams \& Wilkins.

Bernardet, J.-F., Segers, P., Vancanneyt, M., Berthe, F., Kersters, K. \& Vandamme, P. (1996). Cutting a Gordian knot: emended classification and description of the genus Flavobacterium, emended description of the family Flavobacteriaceae, and proposal of Flavobacterium hydatis nom. nov. (basonym, Cytophaga aquatilis Strohl and Tait 1978). Int J Syst Bacteriol 46, 128-148.

Fitch, W. M. (1971). Toward defining the course of evolution: minimum change for a specific tree topology. Syst Zool 20, 406-416.

Groth, I., Schumann, P., Weiss, N., Martin, K. \& Rainey, F. A. (1996). Agrococcus jenensis gen. nov., sp. nov., a new genus of actinomycetes with diaminobutyric acid in the cell wall. Int J Syst Bacteriol 46, 234-239. 
Horn, M. A., Ihssen, J., Matthies, C., Schramm, A., Acker, G. \& Drake, H. L. (2005). Dechloromonas denitrificans sp. nov., Flavobacterium denitrificans sp. nov., Paenibacillus anaericanus sp. nov. and Paenibacillus terrae strain $\mathrm{MH} 72, \mathrm{~N}_{2} \mathrm{O}$-producing bacteria isolated from the gut of the earthworm Aporrectodea caliginosa. Int J Syst Evol Microbiol 55, 1255-1265.

Kim, B. Y., Weon, H. Y., Cousin, S., Yoo, S. H., Kwon, S. W., Go, S. J. \& Stackebrandt, E. (2006). Flavobacterium daejeonense sp. nov. and Flavobacterium suncheonense sp. nov., isolated from greenhouse soils in Korea. Int J Syst Evol Microbiol 56, 1645-1649.

Kumar, S., Tamura, K. \& Nei, M. (2004). MEGA3: integrated software for molecular evolutionary genetics analysis and sequence alignment. Brief Bioinform 5, 150-163.

Mesbah, M., Premachandran, U. \& Whitman, W. B. (1989). Precise measurement of the $\mathrm{G}+\mathrm{C}$ content of deoxyribonucleic acid by high-performance liquid chromatography. Int J Syst Bacteriol 39, 159-167.

Nogi, Y., Soda, K. \& Oikawa, T. (2005). Flavobacterium frigidimaris sp. nov., isolated from Antarctic seawater. Syst Appl Microbiol 28, 310-315.

Park, M., Lu, S., Ryu, S. H., Chung, B. S., Park, W., Kim, C.-J. \& Jeon, C. O. (2006). Flavobacterium croceum sp. nov., isolated from activated sludge. Int J Syst Evol Microbiol 56, 2443-2447.

Saha, P. \& Chakrabarti, T. (2006). Flavobacterium indicum sp. nov., isolated from warm spring water in Assam, India. Int J Syst Evol Microbiol 56, 2617-2621.
Saitou, N. \& Nei, M. (1987). The neighbor-joining method: a new method for reconstructing phylogenetic trees. Mol Biol Evol 4, 406-425.

Thompson, J. D., Higgins, D. G. \& Gibson, T. J. (1994). CLUSTAL W: improving the sensitivity of progressive multiple sequence alignment through sequence weighting, position-specific gap penalties and weight matrix choice. Nucleic Acids Res 22, 4673-4680.

Van Trappen, S., Vandecandelaere, I., Mergaert, J. \& Swing, J. (2005). Flavobacterium fryxellicola sp. nov. and Flavobacterium psychrolimnae sp. nov., novel psychrophilic bacteria isolated from microbial mats in Antarctic lakes. Int J Syst Evol Microbiol 55, 769-772.

Wang, Z. W., Liu, Y. H., Dai, X., Wang, B. J., Jiang, C. Y. \& Liu, S. J. (2006). Flavobacterium saliperosum sp. nov., isolated from freshwater lake sediment. Int J Syst Evol Microbiol 56, 439-442.

Xie, C. H. \& Yokota, A. (2006). Reclassification of [Flavobacterium] ferrugineum as Terrimonas ferruginea gen. nov., comb. nov., and description of Terrimonas lutea sp. nov., isolated from soil. Int J Syst Evol Microbiol 56, 1117-1121.

Yi, H. \& Chun, J. (2006). Flavobacterium weaverense sp. nov. and Flavobacterium segetis sp. nov., novel psychrophiles isolated from the Antarctic. Int J Syst Evol Microbiol 56, 1239-1244.

Yi, H., Oh, H. M., Lee, J. H., Kim, S. J. \& Chun, J. (2005). Flavobacterium antarcticum sp. nov., a novel psychrotolerant bacterium isolated from the Antarctic. Int J Syst Evol Microbiol 55, 637-641.

Yoon, J. H., Kang, S. J. \& Oh, T. K. (2006). Flavobacterium soli sp. nov., isolated from soil. Int J Syst Evol Microbiol 56, 997-1000. 